\title{
Good Governance and Economic Growth in South European Countries
}

\author{
Dimitra Mitsi \\ Correspondence: Department of Economics, University of Piraeus, 80, M. Karaoli \& A. Dimitriou St., 18534 Piraeus, \\ Greece.
}

Received: February 3, 2021

Accepted: March 18, 2021 Online Published: April 6, 2021

doi:10.5539/res.v13n2p26

\author{
URL: https://doi.org/10.5539/res.v13n2p26
}

\begin{abstract}
Economic growth is a prerequisite for economic development. However, there is no "recipe" for countries to create an environment of prosperity and to achieve high rates of economic growth. Many researchers have examined the drivers of economic growth and find that economic growth depends on many economic and institutional variables. In this context, the main objective of this paper is to examine the role of good governance on economic growth in piicgs countries (Portugal, Ireland, Italy, Cyprus, Greece, and Spain). The database was collected from many sources and the empirical analysis is based on a 2SLS (two-stage least squares) technique. In our empirical results, we find that trade openness, gross capital formation, inflation, political stability, rule of law, debt rule, budget balanced rule, and the combination between debt rule/budget balanced rule with political stability and combination between debt rule/budget balanced rule with rule of law are significant drivers of economic growth in piicgs countries while foreign direct investments, government effectiveness, voice and accountability, regulatory quality, fiscal rule index and expenditure rule are insignificant. However, the results may be different if we use other sample groups and/or different periods.
\end{abstract}

Keywords: economic growth, fiscal rules, governance indicators

\section{Introduction}

Economic growth is a broad notion and there is no economic development without economic growth. In general, it's beneficial for countries to achieve high rates of economic growth. it offers new jobs; it brings money and it creates an environment of macroeconomic stability and sustainable development. However, there is no "silver bullet" to do. Many researchers have tried to examine the determinants of economic growth (Cheng and Feng, 2000; Barro, 1999; Bayraktar, 2006; Asheghian, 2009; Checherita-Westphal et al., 2012; Chan and Mendy; 2012) and how they affect it (positively or negatively). Traditionally, researchers focus on macroeconomics determinants like trade openness, foreign direct investments, government expenditures, inflation, direct saving, direct investment, real exchange rate, human capital, etc (Fischer, 1992; Anyanwu, 2014; Dollar, 1992; Radelet et al.,2001; Fetchi-Vehapi et al.,2015).

Reviewing the existence literature, we find that they are many economic factors that affect economic growth. Trade Openness as measured by the sum of exports plus imports as a percentage of GDP is identified as economic growth determinant. However, the results are mixed. Studies by Dollar and Kray (2004), Das and Paul (2011) and Nowbutsing (2014) confirm the positive effect of trade openness on economic growth while Fenira (2015) investigates a not so strong relationship. Similarly, empirical evidence reveals that foreign direct investment has a positive impact on economic growth (Koojaroenprasit, 2012; Shahbaz and Rahman, 2010). However, researches also reveal that foreign direct investment has a negative impact on economic growth (Konings, 2001). Besides, several studies have examined the relationship between gross capital formation and the results are mixed. There are studies that reveal a positive relationship between these variables (Noor Siddiqi, 2010; Bal, Dash and Subhasish, 2016; Khan et al., 2019; Awodumi and Adewuyi, 2020) while Muhammad and Khan (2019) find that gross capital formation has a negative and statistically significant impact on economic growth. Moreover, the size of the government expenditure is also a positive key factor for economic growth (Baldacci et al., 2009; Yasin, 2011; Nwaka and Onifade, 2015). On the other hand, high inflation considered as a factor that destabilizes the economy and as a result it has a generally negative effect on economic growth (Nell, 2000; Mubarik, 2005; Sergi, 2009).

Besides, except economic variables, institutions also play an important role in economic growth (Calderoan and Chong, 2000; Cebula and Fuley, 2011; Ahmad et al., 2012; Drury et al.,2006; Acemoglu et al., 2005; Morita and Zaelke,2007; Alesina et al.,1996). A country with strong institutions can create high rates of economic growth while a country with weak institutions can hamper economic growth. Governance indicators like political stability, rule of law, voice and accountability, government effectiveness, control of corruption, and rule of law -developed by Kaufman et al. (1999)are the key factors for economic growth (Huynch et al, 2009; Rodrik, 2008; Han et al., 2014; Campos and Nugent, 2000; 
Aisen and Veiga, 2013). The first institution to be examined at this point is the effect of political stability on economic growth (Abosedra, 2014; Younis et al., 2008). For instance, Huynh et al. (2009) find that political stability has a positive and significant effect on economic growth. The same results are reported from Han et al. (2014). On the other hand, Alesina (1992) finds that political instability affects negatively economic growth while Pere (2005) cannot support any of the above results. A strong system of legacy is also an important driver for economic growth (Cebula and Foley, 2011; Morita and Zaelke; 2007). In particular, Cebula and Foley (2011) reveal that economic growth is positively connected with regulatory quality while Morita and Zaelke (2007) report that economic growth is not associated with the existence of rules but with the enforcement of them. In addition, Huynh et al. (2009) and Han et al. (2014) find a positive correlation between voice accountability and government effectiveness.

As concerns, the rest of the institutional variables, Acemoglu and Robinson (2010), Emara and Jhonsa (2014), and Kaufman and Kray (2002) give attention to the role of government effectiveness on economic growth. They find that government effectiveness has a positive and statistical significance link with economic growth. However, this link is not universal and researchers of Kurtz et al. (2007) and Quibria (2006) cannot establish a significant impact between government effectiveness and economic growth. Examining the control of corruption with economic growth we find mixed results. More precisely, Mo (2001) reveals that an increase in corruption reduces economic growth while Pere (2015) finds no linkage between these two variables.

Moreover, fiscal rules as a measure of fiscal policy have a prominent role in economic growth. Especially in Europe and after the hit of the crisis of 2008, the European Union strengthened its fiscal policy by adopting 4 national fiscal rules (debt rules, expenditure rules, budget balanced rules, and revenue rules). These rules set quantitative limits on fiscal variables like debt and deficit and European Commission poses penalties to European countries in case of not obey with the rules. Empirical researches have examined fiscal rules (e.g primary balance) and how they impact fiscal outcomes (Alesina and Bayoumi, 1996; Alesina et al., 1999; Debrun et al., 2008; Perotti and Kontopulos, 2002; Badinger \& Reuter, 2017; Caselli \& Reynard, 2020; Mitsi, 2021). However, the literature lacks on how fiscal rules affect economic growth in piicgs countries and how a combination of fiscal rules and governance indicators impact economic growth.

\section{Method}

\subsection{Data}

In our study, we investigate the impact of institutions on economic growth in piicgs countries. We use this country group as these countries were worst hit by the European debt crisis and had many economic problems and especially high rates of economic recession. As a result, the implementation of fiscal rules in these country group was necessary to improve their fiscal aggregates. Our sample has yearly data and all the data was collected from 2002 to 2018. Data are derived from the sources below: 1) World Bank's Worldwide Governance Indicators, 2) World Bank's Worldwide Development Indicators, 3) United Nations Conference on Trade and Development, 3) European Commission Database, and 4) International Monetary Fund (Appendix A).

\subsection{Model Specification}

According to the above the linear equation of the economic growth is given as follows:

$$
\text { rgdpca }=f(t o, f d i, \text { gcf, govcon, inf , inst, fri) }
$$

The equation of the model can be written as follows:

$$
\text { logrgdpca }=\alpha_{i t}+\beta_{1} t o_{i t}+\beta_{2} f d i_{i t}+\beta_{3} g c f_{i t}+\beta_{4} \text { govcon }_{i t}+\beta_{5} i n f_{i t}+\gamma i i_{i t}+u_{i t}+e_{i t}, t=1,2 \ldots t, i=1,2 \ldots n
$$

where

$\alpha, \beta_{1}, \beta_{2}, \beta_{3,} \beta_{3,} \beta_{4}, \beta_{5}$, and $\gamma$ are the unknown coefficient of the explanatory variables. $u_{i t}$ is the effect of each country and $e_{i i}$ is the unobserved zero mean white noise-type. Logarithm of gdp per capita (logrgdpca) expresses the dependent variable and trade openness (to), foreign direct investments (fdi), gross capital formation (gcf), general government final consumption expenditure (govcon), inflation (inf) as independent variables. Moreover variable in expresses a set of institutional variables like rule of law (rl), government effectiveness (ge), political stability (ps), regulatory quality (rq), voice and accountability (va), control of corruption (cc), fiscal rule (fri), debt rule (dr), budget balanced rule (bbr), expenditure rule (er). Finally, i expresses each country and t expresses the period.

Moreover, Globerman et al. (2002) and Buchanan et al. (2012) have reported in their researches that Kaufman et al. (1998) indicators (political stability, rule of law, regulatory quality, government effectiveness, voice and accountability, and control of corruption) have a strong correlation with each other and it's suggested not to include all of the variables in a single regression. In this context, we use the method of Principal Component Analysis (PCA) to construct an overall index (inst) which is comprised of these 6 sub-indices.

A significant concern in our empirical analysis is that some regressors might be endogenous in determining gdp per 
capita. For instance, gdp per capita may be increased due to a higher rate of trade openness and vice versa (a higher trade openness may be increased by higher gdp per capita. At this point, if we run a regression such as: OLS (Ordinary Least Squares), Fixed Effects or Random Effects (we select the appropriate model according to the Hausman test), the estimations would give biased or inappropriate results as there is correlation among error term and explanatory variables. To deal with the problem of endogeneity we apply the technique of 2SLS by using the statistical program -Stata- to make our estimations and we apply the command xtivreg2. In our model, the endogenous variable is trade openness and use as instrumental variable the first lag of trade openness. (Note 1)

\subsection{Descriptive Statistics}

In Figure 1 we present the average real gdp per capita of Portugal, Ireland, Italy, Cyprus, Greece, and Spain from 2002 to 2018.

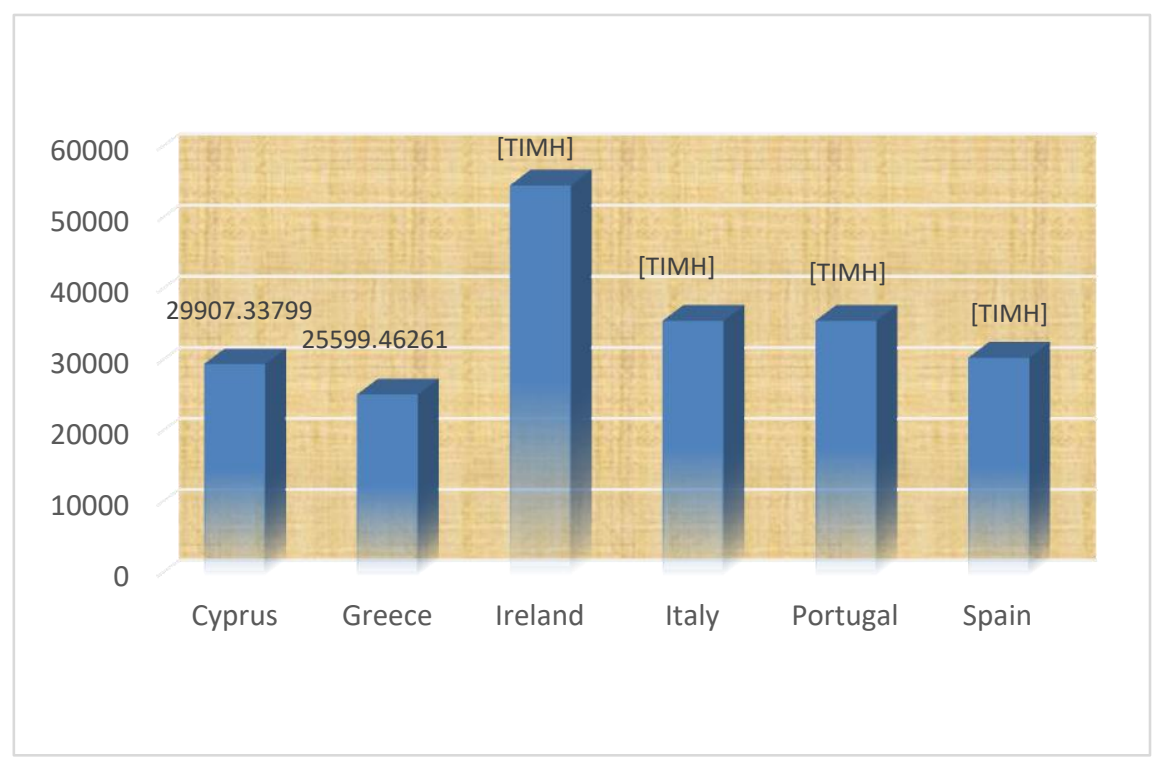

Figure 1. Average real gdp per capita for piicgs countries (2002-2018)

In Figure 2 we present the institutions (political stability, rule of law, government effectiveness, regulatory quality, voice and accountability, and control of corruption) of piicgs countries in 2002 and 2018 respectively. It's noted that these indicators range from -2.5 (weak institutional environment) to +2.5 (strong institutional environment). Among piicgs countries, Ireland has a strong institutional context. In the second position is Spain with very strong government effectiveness and in the third-place are Cyprus and Portugal. Instead, Greece shows a weak institutional environment both in 2002 and 2018.

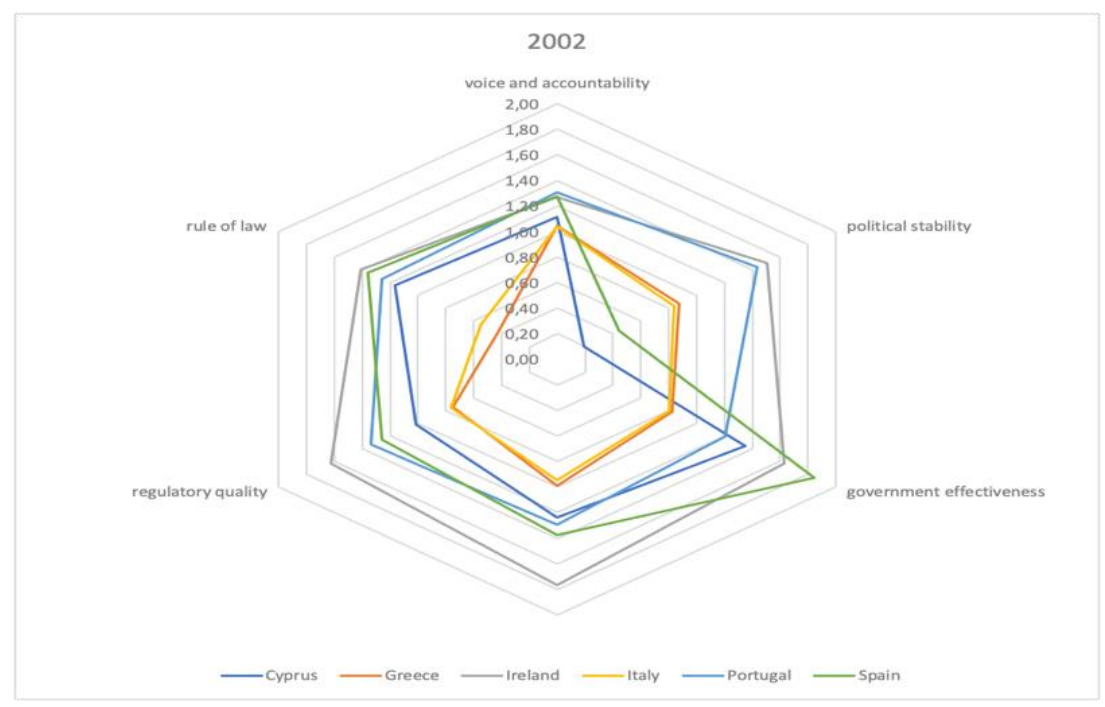

Figure 2. Radar graph of piicgs countries' institutions from 2002 to 2018 
Besides, Figure 3 it's illustrated the fiscal rule index (from 2002 to 2018) for each of the six countries. As we can see, after 2008 all the countries have a high fiscal rule index. This can be explained as a consequence of the financial crisis of 2007-2008. More precisely, the burst of the crisis shows the weaknesses of European countries and the huge deficits that have been created all these years. As a result, European Union tried to strengthen its fiscal policy and to make countries more fiscal disciplined in many ways and especially by adopting fiscal institutions like fiscal rules and fiscal councils.

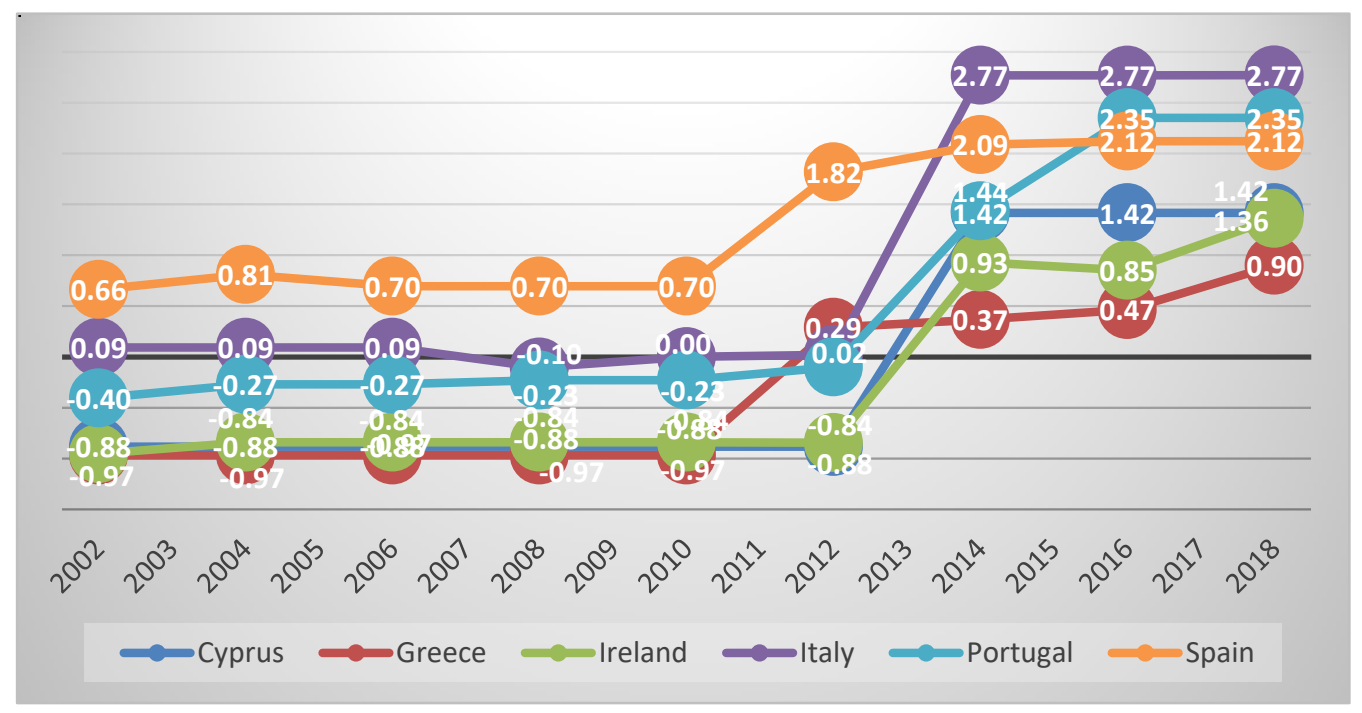

Figure 3. Fri index for piicgs countries from 2002 to 2018

In Table 1, we present the descriptive statistics of Portugal such as mean, standard deviation, min, and max of the variables (logrgdpca, to, fdi, gcf, govcon, inf, inst, and fri) for 18 years (from 2002 to 2018).

Table 1. Descriptive statistics for Portugal

\begin{tabular}{llllcc}
\hline & $\mathrm{N}$ & Mean & Std. Dev. & Min & Max \\
\hline logrgdpca & 17 & 10.0091 & 0.032965 & 9.96443 & 10.08936 \\
to & 17 & 72.2464 & 8.451302 & 61.13895 & 86.99656 \\
fdi & 17 & 8.41344 & 0.648796 & 7.384872 & 9.284315 \\
gcf & 17 & 19.9433 & 3.711595 & 14.63212 & 25.90433 \\
govcon & 17 & 19.2676 & 1.343125 & 16.97713 & 21.30587 \\
inf & 17 & 1.76819 & 1.384184 & -0.83553 & 3.653011 \\
inst & 17 & 0.38891 & 0.299542 & 0 & 1 \\
fri & 17 & 0.05551 & 1.156421 & -0.40465 & 2.351689 \\
\hline
\end{tabular}

In Table 1, we present the descriptive statistics for Portugal. Variable logrgdpca has a mean value equal to 10.0091 while the maximum value is 10.08936 and the minimum value is 9.96443 . The standard deviation is equal to 0.032965 . Variable to has a mean value equal to 72.2464 while the maximum value is 86.99656 and the minimum value is 61.13895 . The standard deviation is equal to 9.451302 . Variable fdi has a mean value equal to 8.41344 while the maximum value is 9.284315 and the minimum value is 7.384872 . The standard deviation is equal to 0.648796 . Variable gcf has a mean value equal to 19.9433 while the maximum value is 25.90433 and the minimum value is 14.63212 . The standard deviation is equal to 3.711595 . Variable govcon has a mean value equal to 19.2676 while the maximum value is 21.30587 and the minimum value is 16.97713 . The standard deviation is equal to 1.343125 . Variable inf has a mean value equal to 1.76819 while the maximum value is 3.653011 and the minimum value is -0.83553 . The standard deviation is equal to 1.384184 . Variable inst has a mean value equal to 0.38891 while the maximum value is 1 and the minimum value is 0 . The standard deviation is equal to 0.299542 . Variable fri has a mean value equal to 10.0091 while the maximum value is 2.351689 and 
the minimum value is -0.40465 . The standard deviation is equal to 1.156421 . The descriptive statistics for other countries are reported in Appendix B.

\section{Presentation of Results}

In Tables 2, 3, and 4, we present the estimation results by using the 2SLS technique while in Table 8, we present the correlation matrix of governance indicators.

In Table 2, we show the effects of governance indicators (ps, ge, va, rl, rq, cc) on economic growth.

Table 2. Panel Data Analysis-2SLS Technique- Effects of governance indicators on economic growth (2002-2018)

\begin{tabular}{|c|c|c|c|c|c|c|c|}
\hline Variables & (A) & (B) & (C) & (D) & (E) & (F) & (G) \\
\hline \multirow[t]{2}{*}{ to } & $0.00428^{* * * *}$ & $0.00458 * * *$ & $0.00395^{* * *}$ & $0.00436^{* * *}$ & $0.00418 * * *$ & $0.00336 * * *$ & $0.00413 * * *$ \\
\hline & $(0.00105)$ & $(0.00126)$ & $(0.00104)$ & $(0.00115)$ & $(0.00111)$ & $(0.00097)$ & $(0.00106)$ \\
\hline \multirow[t]{2}{*}{ fdi } & 0.00294 & 0.00160 & 0.00342 & 0.00063 & 0.00264 & 0.00551 & 0.00241 \\
\hline & $(0.00394)$ & $(0.00374)$ & $(0.00385)$ & $(0.00368)$ & $(0.00366)$ & $(0.00366)$ & $(0.00368)$ \\
\hline \multirow[t]{2}{*}{$\mathrm{gcf}$} & $0.01435^{* * * *}$ & $0.01451 * * *$ & $0.01444 * * *$ & $0.01334 * * *$ & $0.01291 * * *$ & $0.01536 * * *$ & $0.01421 * * *$ \\
\hline & $(0.00178)$ & $(0.00181)$ & $(0.00199)$ & $(0.00193)$ & $(0.00217)$ & $(0.00172)$ & $(0.00187)$ \\
\hline \multirow[t]{2}{*}{ govcon } & 0.01202 & 0.01268 & 0.00968 & 0.00845 & 0.00901 & 0.00820 & 0.00955 \\
\hline & $(0.00825)$ & $(0.00852)$ & $(0.00798)$ & $(0.00823)$ & $(0.00785)$ & $(0.00755)$ & $(0.00812)$ \\
\hline \multirow[t]{2}{*}{ inf } & 0.00452 & 0.00419 & $0.00498^{*}$ & 0.00436 & $0.00515^{*}$ & $0.00467 *$ & 0.00487 \\
\hline & $(0.00295)$ & $(0.00294)$ & $(0.00291)$ & $(0.00304)$ & $(0.00294)$ & $(0.00265)$ & $(0.00296)$ \\
\hline \multirow[t]{2}{*}{ ps } & $0.05365^{* *}$ & & & & & & \\
\hline & $(0.02555)$ & & & & & & \\
\hline \multirow[t]{2}{*}{ ge } & & 0.06529 & & & & & \\
\hline & & $(0.03996)$ & & & & & \\
\hline \multirow[t]{2}{*}{ va } & & & -0.00475 & & & & \\
\hline & & & $(0.05732)$ & & & & \\
\hline \multirow[t]{2}{*}{$\mathrm{rl}$} & & & & $0.07946^{* *}$ & & & \\
\hline & & & & $(0.03483)$ & & & \\
\hline \multirow[t]{2}{*}{$\mathrm{rq}$} & & & & & 0.05200 & & \\
\hline & & & & & $(0.04496)$ & & \\
\hline \multirow[t]{2}{*}{$\mathrm{cc}$} & & & & & & $-0.06200^{* *}$ & \\
\hline & & & & & & $(0.02631)$ & \\
\hline \multirow[t]{2}{*}{ inst } & & & & & & & 0.01281 \\
\hline & & & & & & & $(0.02132)$ \\
\hline \multicolumn{8}{|l|}{ Cragg-Donald } \\
\hline Wald FStatistic & 25.783 & 22.957 & 24.931 & 24.430 & 23.808 & 21.832 & 21.874 \\
\hline \multicolumn{8}{|l|}{ Sargan F } \\
\hline Statistic & 5.314 & 2.208 & 4.006 & 4.324 & 4.767 & 1.879 & 3.411 \\
\hline Observations & 90 & 90 & 90 & 90 & 90 & 90 & 90 \\
\hline R-squared & 0.70772 & 0.70283 & 0.69770 & 0.70555 & 0.69893 & 0.71988 & 0.69591 \\
\hline Number of id & 6 & 6 & 6 & 6 & 6 & 6 & 6 \\
\hline
\end{tabular}

*Denotes $1 \%$ level of significance, $* *$ Denotes $5 \%$ level of significance and *** Denotes $10 \%$ level of significance. In parentheses are the standard errors. 
In Table 3, we present the high correlation between governance indicators and the importance to use each variable separately in our estimation and not altogether because of the problem of multicollinearity.

Table 3. Correlation matrix of governance indicators

\begin{tabular}{ccccccc}
\hline Variables & ps & ge & va & rl & rq & \\
\hline ps & 1.0000 & & & & & \\
ge & 0.4925 & 1.0000 & & & & \\
va & 0.6694 & 0.6874 & 1.0000 & & & \\
rl & 0.5667 & 0.8863 & 0.7955 & 1.0000 & & \\
rq & 0.5494 & 0.7881 & 0.8004 & 0.8720 & 1.0000 & 1.0000 \\
cc & 0.5403 & 0.8892 & 0.7982 & 0.9315 & 0.8610 & \\
\hline
\end{tabular}

In Table 4, we show the effects of fiscal rules (fri, er, dr, bbr) on economic growth.

Table 4. Panel Data Analysis-2SLS Technique- Effects of fiscal rules on economic growth (2002-2018)

\begin{tabular}{|c|c|c|c|c|}
\hline Variables & (A) & (B) & (C) & (D) \\
\hline \multirow[t]{2}{*}{ to } & $0.00390 * * *$ & $0.00397 * * *$ & $0.00409^{* * *}$ & $0.00409 * * *$ \\
\hline & $(0.00105)$ & $(0.00119)$ & $(0.00106)$ & $(0.00106)$ \\
\hline \multirow[t]{2}{*}{ fdi } & 0.00311 & 0.00336 & 0.00233 & 0.00233 \\
\hline & $(0.00403)$ & $(0.00374)$ & $(0.00391)$ & $(0.00391)$ \\
\hline \multirow[t]{2}{*}{ gef } & $0.01464 * * *$ & $0.01437 * * *$ & $0.01435 * * *$ & $0.01435^{* * *}$ \\
\hline & $(0.00186)$ & $(0.00195)$ & $(0.00179)$ & $(0.00179)$ \\
\hline \multirow[t]{2}{*}{ govcon } & 0.01058 & 0.00967 & 0.01033 & 0.01033 \\
\hline & $(0.00847)$ & $(0.00767)$ & $(0.00809)$ & $(0.00809)$ \\
\hline \multirow[t]{2}{*}{ inf } & $0.00535^{*}$ & $0.00500^{*}$ & $0.00570 *$ & $0.00570^{*}$ \\
\hline & $(0.00312)$ & $(0.00291)$ & $(0.00298)$ & $(0.00298)$ \\
\hline \multirow[t]{2}{*}{ fri } & 0.00290 & & & \\
\hline & $(0.00769)$ & & & \\
\hline \multirow[t]{2}{*}{ er } & & -0.00025 & & \\
\hline & & $(0.01820)$ & & \\
\hline \multirow[t]{2}{*}{$\mathrm{dr}$} & & & $0.03833^{* *}$ & \\
\hline & & & $(0.01593)$ & \\
\hline \multirow[t]{2}{*}{ bbr } & & & & $0.03833 * *$ \\
\hline & & & & $(0.01593)$ \\
\hline \multicolumn{5}{|l|}{ Cragg-Donald Wald } \\
\hline FStatistic & 24.428 & 21.458 & 25.389 & 25.389 \\
\hline Sargan F Statistic & 2.859 & 3.495 & 3.504 & 3.504 \\
\hline Observations & 90 & 90 & 90 & 90 \\
\hline R-squared & 0.69888 & 0.69737 & 0.69741 & 0.69741 \\
\hline Number of id & 6 & 6 & 6 & 6 \\
\hline
\end{tabular}

*Denotes $1 \%$ level of significance, $* *$ Denotes $5 \%$ level of significance and *** Denotes $10 \%$ level of significance. In parentheses are the standard errors.

Finally, in Table 5, we present the interaction effects of governance indicators and fiscal rules and their impact on 
economic growth.

Table 5. Panel Data Analysis-2SLS Technique- Interactions effects of governance indicators and fiscal rules on economic growth (2002-2018)

\begin{tabular}{|c|c|c|c|c|c|c|}
\hline Variables & (A) & (B) & (C) & (D) & (E) & (F) \\
\hline \multirow[t]{2}{*}{ to } & $0.00439 * * *$ & $0.00439 * * *$ & $0.00448 * * *$ & $0.00448 * * *$ & $0.00350 * * *$ & $0.00350^{* * *}$ \\
\hline & $(0.00105)$ & $(0.00105)$ & $(0.00114)$ & $(0.00114)$ & $(0.00100)$ & $(0.00100)$ \\
\hline \multirow[t]{2}{*}{ fdi } & 0.00214 & 0.00214 & -0.00047 & -0.00047 & 0.00564 & 0.00564 \\
\hline & $(0.00393)$ & $(0.00393)$ & $(0.00392)$ & $(0.00392)$ & $(0.00422)$ & $(0.00422)$ \\
\hline \multirow[t]{2}{*}{$\operatorname{gcf}$} & $0.01432 * * *$ & $0.01432 * * *$ & $0.01349 * * *$ & $0.01349 * * *$ & $0.01495 * * *$ & $0.01495^{* * *}$ \\
\hline & $(0.00180)$ & $(0.00180)$ & $(0.00191)$ & $(0.00191)$ & $(0.00175)$ & $(0.00175)$ \\
\hline \multirow[t]{2}{*}{ govcon } & 0.01256 & 0.01256 & 0.00973 & 0.00973 & 0.00820 & 0.00820 \\
\hline & $(0.00829)$ & $(0.00829)$ & $(0.00816)$ & $(0.00816)$ & $(0.00770)$ & $(0.00770)$ \\
\hline \multirow[t]{2}{*}{$\inf$} & $0.00504 *$ & $0.00504 *$ & $0.00561^{*}$ & $0.00561^{*}$ & 0.00406 & 0.00406 \\
\hline & $(0.00292)$ & $(0.00292)$ & $(0.00298)$ & $(0.00298)$ & $(0.00284)$ & $(0.00284)$ \\
\hline \multirow[t]{2}{*}{ psbbr } & $0.05499 * *$ & & & & & \\
\hline & $(0.02391)$ & & & & & \\
\hline \multirow[t]{2}{*}{ psdr } & & $0.05499 * *$ & & & & \\
\hline & & $(0.02391)$ & & & & \\
\hline \multirow[t]{2}{*}{ rlbbr } & & & $0.06329 * * *$ & & & \\
\hline & & & $(0.02374)$ & & & \\
\hline \multirow[t]{2}{*}{ rldr } & & & & $0.06329^{* * *}$ & & \\
\hline & & & & $(0.02374)$ & & \\
\hline \multirow[t]{2}{*}{ ccbbr } & & & & & -0.03347 & \\
\hline & & & & & $(0.02816)$ & \\
\hline \multirow[t]{2}{*}{ ccdr } & & & & & & -0.03347 \\
\hline & & & & & & $(0.02816)$ \\
\hline \multicolumn{7}{|l|}{ Cragg-Donald Wald } \\
\hline FStatistic & 25.783 & 25.783 & 24.430 & 24.430 & 21.832 & 21.832 \\
\hline Sargan F Statistic & 5.314 & 5.314 & 4.324 & 4.324 & 1.879 & 1.879 \\
\hline Observations & 90 & 90 & 90 & 90 & 90 & 90 \\
\hline R-squared & 0.70757 & 0.70757 & 0.70300 & 0.70300 & 0.70923 & 0.70923 \\
\hline Number of id & 6 & 6 & 6 & 6 & 6 & 6 \\
\hline
\end{tabular}

$*$ Denotes $1 \%$ level of significance, $* *$ Denotes $5 \%$ level of significance and $* * *$ Denotes $10 \%$ level of significance. In parentheses are the standard errors.

\section{Discussion}

In Table 2, the results in 7 columns (Model (A), Model (B), Model (C), Model (D), Model (E), Model (F), Model(G) show that the coefficient of Trade Openess is positive (0.00428 in Model (A), 0.00458 in Model (B), 0.00395 in Model (C), 0.00436 in Model (D), 0.00418 in Model (E), 0.00336 in Model (F), 0.00413 in Model (G)). This positive impact in each model is statistically significant at a $1 \%$ level and it means that an increase in trade openness will lead to an increase in real gdp per capita. More precisely, a $1 \%$ increase of trade openness will lead to $0.00428 \%$ increase in real gdp per capita in Model (A), $0.00458 \%$ in Model (B), $0.00395 \%$ in Model (C), $0.00436 \%$ in Model (D), $0.00418 \%$ in Model (E), $0.00336 \%$ in $\operatorname{Model}(\mathrm{F})$ and $0.00413 \%$ in $\operatorname{Model}(\mathrm{G})$. 
The coefficient of gross capital formation is also positive for the 7 models. This means that a $1 \%$ increase in gross capital formation will cause an increase in real gdp per capita equal to $0.01435 \%$ in Model (A), $0.01451 \%$ in Model (B), $0.01444 \%$ in Model (C), $0.01334 \%$ in Model (D), 0.01291\% in Model (E), $0.01536 \%$ in Model (F) and $0.01421 \%$ in Model (G). It's noted that the impact of gross capital formation on real gdp per capita (in 7 models) is statistically significant at a $1 \%$ level. The coefficient of inflation is positive and statistically significant only in Model (C), Model (D) and Model (E) at a 10\% level of significance. In particular, a $1 \%$ increase in inflation will cause an increase of $0.0048 \%$ in real gdp per capita in Model (C), $0.00515 \%$ in Model (E), and $0.00467 \%$ in Model (F).

Among institutions of political stability, government effectiveness voice and accountability, rule of law, regulatory quality, and control of corruption, only three have a statistically significant impact on real gdp per capita. These are political stability, rule of law, and control of corruption. Coefficients of political stability and rule of law are positive while the coefficient of control of corruption is negative. This means that a $1 \%$ increase in political stability will cause an increase equal to $0.05365 \%$ in real gdp per capita. A $1 \%$ increase in rule of law index will cause an increase of $0.07946 \%$ in real gdp per capita while a $1 \%$ increase in control of corruption index will cause a decrease of $0.062 \%$ in real gdp per capita.

In Table 3, governance indicators show a high and positive correlation among them. For instance, control of corruption and rule of law have a positive correlation equal to $93.15 \%$. Rule of law and government effectiveness have a positive correlation equal to $88.63 \%$ while regulatory quality and voice and accountability have a positive correlation equal to $80.04 \%$. The same results are reported with other governance indicators (see Table 3).

In Table 4, the results in 4 columns present the effects of fiscal rules on economic growth. Models (A), (B), (C) and (D) show positive coefficients for trade openness, gross capital formation, inflation, debt rules, and budget balanced rules. This means that an increase in trade openness, gross capital formation, inflation, debt rules, and budget balanced rules will lead to an increase in real gdp per capita. For instance, a $1 \%$ increase in debt rule will increase real gdp per capita by $0.03833 \%$. The same results are reported for budget balanced rules (this happens as countries in our sample have adopted the same number of debt rules and budget and balanced rules at the same year period).

Finally, in Table 5, the results in 6 columns present the interaction effects of governance indicators and fiscal rules on economic growth. Models (A) to (F) show positive coefficients for trade openness, gross capital formation, and inflation. Also, we find a positive effect of political stability and budget balanced rule/debt rule on economic growth equal to 0.05499 and a positive effect of rule law and budget balanced rule/debt rule on economic growth equal to 0.06329 .

\section{Conclusion}

In this study, we investigate the role of good governance on economic growth in piicgs countries. We use a sample of 6 countries from 2002 to 2018 and we apply the 2SLS technique in our econometric analysis.

From the findings above, we can observe that foreign direct investments, government effectiveness, voice and accountability, regulatory quality, fiscal rule index, and expenditure rule are insignificant explanatory variables by using the technique of 2SLS. However, the findings also show that trade openness, gross capital formation, inflation, political stability, rule of law, debt rule, budget balanced rule, and the combination between debt rule/budget balanced rule with political stability and combination between debt rule/budget balanced rule with rule of law have significant and positive effects on real gdp per capita and should be considered as significant factors of real gdp per capita in piicgs countries. On the other hand, control of corruption shows a negative impact on economic growth.

Also, it's evident that among institutions the most effective governance indicator on economic growth is rule of law with an effect equal to 0.07946 . The second position places the combination between rule of law and debt rule/budget balanced rule (0.06329) and the third position is the combination between political stability and debt rule/budget balanced rule (0.05499). In the last position, is political stability (0.05365).

The results, of the empirical analysis, have policy recommendations and suggest that piicgs countries can achieve higher rates of economic growth by adopting fiscal rules and by having an environment of good governance. In particular, policymakers should give more attention to debt rules and budget balanced rules as well to political stability, rule of law, and their combinations (political stability with debt rules/ budget balanced rules and rule of law with debt rules/ budget balanced rules).

\section{References}

Acemoglu, D., Johnson, S., \& Robinson, J. (2004). Institutions as the fundamental cause of long-run growth. Working Paper 10481. National Bureau of Economic Research. Cambridge. https://doi.org/10.3386/w10481

Ahmad, E., Ullah, M. A., \& Arfeen, M. I. (2012). Does corruption affect economic growth? Latin American journal of economics, 49(2), 277-305. https://doi.org/10.7764/LAJE.49.2.277

Alesina, A., \& Bayoumi, T. (1996). The costs and benefits of fiscal rules: Evidence from U.S. states. NBER Working 
Paper 5614. National Bureau of Economic Research. Cambridge. https://doi.org/10.3386/w5614

Alesina, A., \& Tabellini, G. (1990). A positive theory of fiscal deficits \& government debt. Review of Economic Studies, 57(3), 407-414. https://doi.org/10.2307/2298021

Alesina, A., Ozler, S., Roubini, N., \& Swagel, P. (1992). Political instability and economic growth. NBER Working Paper Series: no.4173. National Bureau of Economic Research. Cambridge. https://doi.org/10.3386/w4173

Anyanwu, J. C. (2014). Factors Affecting Economic Growth in Africa: Are there any lessons from China? African Development Review, 26(3), 468-493. https://doi.org/10.1111/1467-8268.12105

Asheghian, P. (2009). Determinants of Economic Growth in Japan: The role of foreign direct investment. Global Economy Journal, 9(3), 1-9. https://doi.org/10.2202/1524-5861.1509

Awodumi, O. B., \& Adewuyi, A. O. (2020). The role of non-renewable energy consumption in economic growth and carbon emission: evidence from oil producing economies in Africa. Energy Strategy Rev., $27,100434$. https://doi.org/10.1016/j.esr.2019.100434

Badinger, H., \& Reuter, W. H. (2017). The case of fiscal rules. Economic Modelling, 60, $334-343$. https://doi.org/10.1016/j.econmod.2016.09.028

Bal, D. P., Dash, D. V., \& Subhasish, B. (2016). The effects of capital formation on economic growth in India: evidence from ARDL-bound testing approach. Global Bus. Rev., 17(6), 1388-1400. https://doi.org/10.1177/0972150916660403

Baldacci, E., Clements, B., Gupta, S., \& Cui, Q. (2008). Social spending, human capital, and growth in developing countries. World Dev., 36(8), 1317-1341. https://doi.org/10.1016/j.worlddev.2007.08.003

Barro, R. J. (1999). Determinants of Economic Growth: Implications of the Global Evidence for Chile. Cuadernos de Economía, 36(107), 443-478.

Bayraktar, B. (2006). Investigation on Sources of Growth for Turkey. Canadian Journal of Development, 27(1), 25-38. https://doi.org/10.1080/02255189.2006.9669118

Caselli, F., \& Reynard, J. (2020). Do fiscal rules cause better fiscal balances? A new instrumental variable strategy. European Journal of Political Economy, 63(C). https://doi.org/10.1016/j.ejpoleco.2020.101873

Cebula, R., \& Foley, M. (2011). A Panel Data Study of the Effects of Economic Freedom, Regulatory Quality, and Taxation on the Growth Rate of Per Capita Real GDP. Journal of Public Finance and Public Choice, 30(1-3), 103-122 https://doi.org/10.1332/251569212X15664519360506

Chang, C., \& Mendy, M. (2012). Economic Growth and Openness in Africa: What is the empirical relationship? Applied Economics Letters, 19(18), 1903-1907. https://doi.org/10.1080/13504851.2012.676728

Checherita-Westphal, C., \& Rother, P. (2012). The Impact of High Government Debt on Economic Growth and its Channels: An empirical investigation for the Euro area. European Economic Review, 56, 1392-1405. https://doi.org/10.1016/j.euroecorev.2012.06.007

Chen, B., \& Feng, Y. (2000). Determinants of Economic Growth in China: Private enterprise, education, and openness. China Economic Review, 11, 1-15. https://doi.org/10.1016/S1043-951X(99)00014-0

Das, A., \& Paul, B. P. (2011). Openness and growth in emerging Asian economies: Evidence from GMM estimations of a dynamic panel. Economics Bulletin, 31, 2219-2228. Retrieved from https://d1wqtxts1xzle7.x

Debrun, X., Moulin, L., Turrini, A., Ayuso-i-Casalas, J., \& Kumar, M. S. (2008). Tied to the mast? National fiscal rules in the European Union. Economic Policy, 23(54), 297-362. http://dx.doi.org/10.1111/j.1468-0327.2008.00199.x

Dollar, D. (1992). Outward-Oriented Developing Economies Really Do Grow more rapidly: Evidence form 95 LDCs, 1976-1985. Economic Development and Cultural Change, 40(3), 523-544. http://dx.doi.org/10.1086/451959

Dollar, D., \& Kraay, A. (2004). Trade. Growth and Poverty. Economic Journal, 114, 22-49 https://doi.org/10.1111/j.0013-0133.2004.00186.x

Drury, A. C., Krieckhaus, J., \& Lusztig, M. (2006). Corruption, democracy, and economic growth. International Political Science Review, 27(2), 121-136. https://doi.org/10.1177/0192512106061423

Emara, N., \& Jhonsa, E. (2014). Governance and economic growth: interpretation for MENA countries. Topics in Middle Eastern and African Economies, 16(2), 164-183. Retrieved from https://meea.sites.luc.edu/volume16/pdfs/Emara-Jhonsa.pdf

Fenira, M. (2015). Trade openness and growth in developing countries: An analysis of the relationship after comparing 
trade indicators. Asian Economic and Financial Review, 5, 468-482. https://doi.org/10.18488/journal.aefr/2015.5.3/102.3.468.482

Fetahi-Vehapi, M., Sadiku, L., \& Petkovski, M. (2015). Empirical Analysis of the effects of Trade Openness on Economic Growth: An evidence of South East European countries. Procedia Economics and Finance, 19, 17-26. https://doi.org/10.1016/S2212-5671(15)00004-0

Fischer, S. (1992). Macroeconomic Stability and Growth. Cuadernos de Economía, 29(87), 171-186. https://doi.org/10.1016/j.egyr.2019.08.004

Huynh, K. P., \& Jacho-Chavez, D. T. (2009). Growth and governance: A nonparametric analysis. Journal of Comparative Economics, 37(1), 121-143. https://doi.org/10.1016/j.jce.2008.08.003

Kaufmann, D., \& Kraay, A. (2002). Growth without governance. Policy research working paper no. 2928: The World Bank. Retrieved from http://hdl.handle.net/10986/19206

Kaufmann, D., Kraay, A., \& Zoido-Lobat6n, P. (1999). Governance matters. Finance Dev, 37(2), 10. Retrieved from https://www.imf.org/external/pubs/ft/fandd/2000/06/pdf/kauf.pdf

Khan, S., Peng, Z., \& Li, Y. (2019). Energy consumption, environmental degradation, economic growth and financial development in globe: Dynamic simultaneous equations panel analysis. Energy Reports, 5, 1089-1102.

Konings, J. (2001). The effects of foreign direct investment on domestic firms: Evidence from firm-level panel data in emerging economies. Economics of transition, 9(3), 619-633. https://doi.org/10.1111/1468-0351.00091

Koojaroenprasit, S. (2012). The impact of foreign direct investment on economic growth: A case study of South Korea. International Journal of Business and Social Science, 3(21). Retrieved from https://core.ac.uk/download/pdf/51179393.pdf

Kurtz, M., \& Schrank, A. (2007). Growth and governance: Models, measures and mechanisms. Journal of Politics, 69(2), 538-554. https://doi.org/10.1111/j.1468-2508.2007.00549.x

lesina, A., Ozler, S., Roubini, N., \& Swagel, P. (1996). Political instability and economic growth. Journal of Economic growth, l(2), 189-211. https://doi.org/10.1007/BF00138862

Mitsi, D. (2021). Does the quality of Fiscal Institutions matter for fiscal Performance? A panel data analysis of European Countries. International Journal of Economics and Finance, 13(1), 33-44. https://doi.org/10.5539/ijef.v13n1p33

Mo, P. H. (2001). Corruption and economic growth. Journal of Comparative Economics, 29, 66-70. Viewed. 03 October 2016. https://doi.org/10.1006/jcec. 2000.1703

Morita, S., \& Zaelke, (2005, April). Rule of law, good governance, and sustainable development. Paper presented at the Seventh International Conference on Environmental Compliance and Enforcement, Marrakech, Morocco. Abstract retrieved from https://nepis.epa.gov

Mubarik, Y. A. (2005). Inflation and growth: An estimate of the threshold level of inflation in Pakistan. SBP-Research Bulletin, Volume 1, No. 1, pp. 35-43. Retrieved from https://www.researchgate.net/publication/311413446_Inflation_and_Growth_An_Estimate_of_the_Threshold_Lev el_of_Inflation_in_the_US

Muhammad, B. (2019). Energy consumption, CO2 emissions and economic growth in developed, emerging and Middle East and North Africa countries. Energy, 179, 232-245. https://doi.org/10.1016/j.energy.2019.03.126

Nell, K. (2000). Is Low Inflation a Precondition for Faster Growth, The Case of South Africa. Department of Economics, University of Kent, United Kingdom. Retrieved from https://www.kent.ac.uk/economics/repec/0011.pdf

Noor, S., \& Siddiqi, M. W. (2010). Energy consumption and economic growth in South Asian countries: a co-integrated panel analysis. International Journal of Energy and Power Engineering, 4(7), 1731-1736.

Nowbutsing, B. M. (2014). The impact of openness on economic growth: Case of Indian Ocean rim countries. Journal of Economics and Development Studies, 2, 407-427. Retrieved from http://jedsnet.com/journals/jeds/Vol_2_No_2_June_2014/23.pdf

Nwaka, I. D., \& Onifade, S. T. (2015) Government size, openness and income risk Nexus: new evidence from Some African countries (No. WP/15/056). In: AGDI working paper. Retrieved from https://www.researchgate.net/publication/296677127_Government_Size_Openness_and_Income_Risk_Nexus_Ne w_Evidence_from_Some_African_Countries 
Pere, E. (2015). The impact of good governance in the economic development of Western Balkan Countries. European Journal of Government and Economics, 14(1), 25-45. https://doi.org/10.17979/ejge.2015.4.1.4305

Perotti, R., \& Yianos, K. (2002). Fragmented Fiscal Policy. Journal of Public Economics, 86(2), 191-222. https://doi.org/10.1016/S0047-2727(01)00146-3

Quibria, M. G. (2006). Does Governance Matter? Yes, No or Maybe: Some Evidence from Developing Asia. Kyklos, 59(1), 99-114. https://doi.org/10.1111/j.1467-6435.2006.00322.x

Radelet, S., Sachs, J., \& Whang-Lee, J. (2001). The Determinants and Prospects of Economic Growth in Asia. International Economic Journal, 15(3), 1-29. https://doi.org/10.1080/10168730100000041.

Sergii, P. (2009). Inflation and Economic Growth: The Non-Linear relationship. Evidence from CIS Countries. Kyiv School of Economics. Retrieved from http://www.kse.org.ua/uploads/file/Pypko.pdf

Shahbaz, M., \& Mohammad, M. R. (2010). Foreign capital inflows-growth nexus and role of domestic financial sector: An ARDL co-integration approach for Pakistan. J. Econ. Res., 15, 207-31.

Tang, C. F., \& Abosedra, S. (2014). The impacts of tourism, energy consumption and political instability on economic growth in the MENA countries. Energy Policy, 68, 458-464. https://doi.org/10.1016/j.enpol.2014.01.004

Yasin, M. (2011). Public spending and economic growth: empirical investigation of Sub-Saharan Africa. South western $\begin{array}{lllll}\text { Econ. } & \text { Rev., } & 30(5), & 9-68 . & \text { Retrieved }\end{array}$ http://citeseerx.ist.psu.edu/viewdoc/download?doi=10.1.1.531.9796\&rep=rep1\&type=pdf

Younis, M., Lin, X. X., Sharahili, Y., \& Selvarathinam, S. (2008). Political Stability and Economic Growth in Asia. American Journal of Applied Sciences, 5(3), 203-208. https://doi.org/10.3844/ajassp.2008.203.208

\section{Notes}

Note 1. We cannot use the GMM approach to deal with the problems of heterogeneity, autocorrelation and endogeneity as the number of countries are less than the number of periods.

\section{Appendix A}

Table A1. Variables, Definitions and Sources

\begin{tabular}{|c|c|c|}
\hline Variables & Definition & Sources \\
\hline Trade Openness (to) & $\begin{array}{l}\text { Sum of exports plus imports as a } \\
\text { percentage of GDP }\end{array}$ & Worldwide Development Indicators \\
\hline Foreign direct investments (fdi) & $\begin{array}{l}\text { Net inflows of investment as a percentage } \\
\text { of GDP }\end{array}$ & $\begin{array}{l}\text { United Nations Conference on Trade and } \\
\text { Development }\end{array}$ \\
\hline Gross capital formation (gcf) & $\begin{array}{l}\text { Value of additions to fixed and net changes } \\
\text { of inventories as a percentage of GDP }\end{array}$ & Worldwide Development Indicators \\
\hline Government consumption(govcon) & $\begin{array}{l}\text { General government final consumption } \\
\text { expenditure as a percentage of GDP }\end{array}$ & Worldwide Development Indicators \\
\hline Inflation (inf) & Percentage change of consume price index & Worldwide Development Indicators \\
\hline Gdp per capita (logrgdpca) & $\begin{array}{l}\text { Log of gross domestic product per person } \\
\text { in constant prices (constant } 2010 \text { US\$) }\end{array}$ & Worldwide Development Indicators \\
\hline Rule of law index (rl) & $\begin{array}{l}\text { It measures the extent to which citizen } \\
\text { abide by the rules of the society. It ranges } \\
\text { between }-2.5 \text { (weak index of rule of law) to } \\
+2.5 \text { (strong index of rule of law) }\end{array}$ & Worldwide Governance Indicators \\
\hline Voice and Accountability (va) & $\begin{array}{l}\text { It measures the extent to which citizen has } \\
\text { the freedom of expression. It ranges } \\
\text { between }-2.5 \text { (weak index of voice and } \\
\text { accountability) to }+2.5 \text { (strong index of } \\
\text { voice and accountability) }\end{array}$ & Worldwide Governance Indicators \\
\hline
\end{tabular}


Control of corruption (cc)

Government effectiveness (ge)

Political Stability (ps)

Regulatory quality (rq)

Fiscal rule Index

Budget Balanced Rule dummy (bbr)

Debr Rule Dummy (dr)

Expenditure rule dummy
It measures the extent to which policymakers interested for private gain. It ranges between -2.5 (weak index of control of corruption) to +2.5 (strong index of control of corruption)

It measures the extent to which public services are independent from political interferences, and the degree of civil service quality. It ranges between -2.5 (weak index of government effectiveness) to +2.5 (strong index of government effectiveness)

It measures the existence of political instability. It ranges between -2.5 (weak index of political stability) to +2.5 (strong index of political stability)

It measures the extent to which policymakers implement sound policies. It ranges between -2.5 (weak index of regulatory quality) to +2.5 (strong index of regulatory quality)

It measures the strength of fiscal rules based on the statutory of the rules, the correction mechanisms, the monitoring bodies and the binding character of the rule.

It takes value 1 if a budget balanced rule is in place, and 0 otherwise

It takes value 1 if a debt rule is in place, and 0 otherwise

It takes value 1 if an expenditure rule is in place, and 0 otherwise
Worldwide Governance Indicators

Worldwide Governance Indicators

Worldwide Governance Indicators

Worldwide Governance Indicators

European Commission Dataset

International Monetary Fund Dataset

International Monetary Fund Dataset

International Monetary Fund Dataset

\section{Appendix B}

Table B1. Descriptive statistics for Ireland

\begin{tabular}{|c|c|c|c|c|c|}
\hline & $\mathrm{N}$ & Mean & Std. Dev. & Min & Max \\
\hline logrgdpca & 17 & 10.9030 & 0.154134 & 10.77042 & 11.24717 \\
\hline to & 17 & 180.828 & 27.80252 & 146.5523 & 226.0414 \\
\hline fdi & 17 & 10.6235 & 0.617828 & 10.03369 & 12.29165 \\
\hline gcf & 17 & 25.2471 & 5.815608 & 17.08068 & 37.41433 \\
\hline govcon & 17 & 16.0162 & 2.541244 & 11.90030 & 20.13667 \\
\hline inf & 17 & 1.51267 & 2.401802 & -4.47810 & 4.897116 \\
\hline inst & 17 & 0.65009 & 0.346041 & 0 & 1 \\
\hline fri & 17 & -0.18657 & 0.950634 & -0.95247 & 1.361246 \\
\hline
\end{tabular}


Table B2. Descriptive statistics for Italy

\begin{tabular}{|c|c|c|c|c|c|}
\hline & $\mathrm{N}$ & Mean & Std. Dev. & Min & Max \\
\hline logrgdpca & 17 & 10.49007 & 0.041354 & 10.42426 & 10.55248 \\
\hline to & 17 & 53.11629 & 4.376471 & 45.41876 & 60.51154 \\
\hline fdi & 17 & 9.732274 & 1.438425 & 4.527317 & 10.68852 \\
\hline gcf & 17 & 19.67108 & 1.976765 & 16.89239 & 22.24605 \\
\hline govcon & 17 & 19.4366 & 0.584313 & 18.5460 & 20.67864 \\
\hline inf & 17 & 1.675908 & 1.045108 & -0.09401 & 3.347833 \\
\hline inst & 17 & 0.038522 & 0.271767 & 0 & 1 \\
\hline fri & 17 & 0.837548 & 1.291174 & -0.10005 & 2.796741 \\
\hline
\end{tabular}

Table B3. Descriptive statistics for Cyprus

\begin{tabular}{lllccc}
\hline & $\mathrm{N}$ & Mean & Std. Dev. & Min & Max \\
\hline logrgdpca & 17 & 10.3041 & 0.060326 & 10.19743 & 10.39591 \\
to & 17 & 120.865 & 13.93982 & 102.7909 & 146.4048 \\
fdi & 17 & 9.06243 & 1.572787 & 6.79284 & 11.09665 \\
gcf & 17 & 19.9994 & 4.500670 & 12.92516 & 28.95597 \\
govcon & 17 & 17.0375 & 1.373658 & 14.68574 & 19.08799 \\
inf & 17 & 1.54438 & 1.972809 & -2.09699 & 4.669008 \\
inst & 17 & 0.60446 & 0.299893 & 0 & 1 \\
fri & 17 & 0.09248 & 1.106206 & -0.88273 & 1.418389 \\
\hline
\end{tabular}

Table B4. Descriptive statistics for Greece

\begin{tabular}{llllcc}
\hline & N & Mean & Std. Dev. & Min & Max \\
\hline logrgdpca & 17 & 10.1446 & 0.1096762 & 10.01015 & 10.31078 \\
to & 17 & 57.8448 & 7.437514 & 47.74385 & 72.5197 \\
fdi & 17 & 7.35413 & 1.184959 & 3.677712 & 8.585765 \\
gcf & 17 & 18.3202 & 6.450568 & 10.21701 & 27.37489 \\
govcon & 17 & 20.4600 & 1.192763 & 18.95885 & 23.30901 \\
inf & 17 & 1.85611 & 2.073864 & -1.73603 & 4.712973 \\
inst & 17 & 0.57995 & 0.347773 & 0 & 1 \\
fri & 17 & -0.35690 & 0.768070 & -0.96544 & 0.901754
\end{tabular}

Table B5. Descriptive statistics for Spain

\begin{tabular}{|c|c|c|c|c|c|}
\hline & $\mathrm{N}$ & Mean & Std. Dev. & Min & Max \\
\hline logrgdpca & 17 & 10.3341 & 0.038565 & 10.27197 & 10.40272 \\
\hline to & 17 & 58.5566 & 5.586084 & 46.99487 & 67.51969 \\
\hline fdi & 17 & 10.2860 & 0.544500 & 9.054648 & 11.25146 \\
\hline gcf & 17 & 23.4474 & 4.886345 & 17.2157 & 30.56535 \\
\hline govcon & 17 & 18.7673 & 1.391445 & 16.62433 & 20.67171 \\
\hline inf & 17 & 2.01355 & 1.489165 & -0.50046 & 4.075661 \\
\hline inst & 17 & 0.53059 & 0.298303 & 0 & 1 \\
\hline fri & 17 & 1.30288 & 0.652418 & 0.664202 & 2.123073 \\
\hline
\end{tabular}

\section{Copyrights}

Copyright for this article is retained by the author(s), with first publication rights granted to the journal.

This is an open-access article distributed under the terms and conditions of the Creative Commons Attribution license (http://creativecommons.org/licenses/by/4.0/). 